\title{
Source segregation of food waste in office areas: Factors affecting waste generation rates and quality
}

Edjabou, Vincent Maklawe Essonanawe; Boldrin, Alessio; Scheutz, Charlotte; Astrup, Thomas Fruergaard

Published in:

Waste Management

Link to article, DOI:

10.1016/j.wasman.2015.07.013

Publication date:

2015

Document Version

Peer reviewed version

Link back to DTU Orbit

Citation (APA):

Edjabou, V. M. E., Boldrin, A., Scheutz, C., \& Astrup, T. F. (2015). Source segregation of food waste in office areas: Factors affecting waste generation rates and quality. Waste Management, 46, 94-102.

https://doi.org/10.1016/j.wasman.2015.07.013

\section{General rights}

Copyright and moral rights for the publications made accessible in the public portal are retained by the authors and/or other copyright owners and it is a condition of accessing publications that users recognise and abide by the legal requirements associated with these rights.

- Users may download and print one copy of any publication from the public portal for the purpose of private study or research.

- You may not further distribute the material or use it for any profit-making activity or commercial gain

- You may freely distribute the URL identifying the publication in the public portal 
1 First revision of manuscript.

2

Source segregation of food waste in office areas:

4 factors affecting waste generation rates and quality Fruergaard Astrup

12 Department of Environmental Engineering, Technical University of Denmark, 2800 Kgs. Lyngby, Denmark

*) Corresponding author: vine@env.dtu.dk; 


\section{Abstract}

23 Existing legislation mandates that the amount of waste being recycled should be

24 increased. Among others, in its Resource Strategy Plan, the Danish Government decided that at least $60 \%$ of food waste generated by the service sector, including in office areas, should be source-sorted and collected separately by 2018. To assess the achievability of these targets, source-sorted food waste and residual waste from office areas was collected and weighed on a daily basis during 133 working days. Waste composition analyses were conducted every week to investigate the efficiency of the source-sorting campaign and the purity of the source-sorted food waste. The moisture content of source-sorted food waste and residual waste fractions, and potential methane production from source-sorted food waste, was also investigated.

Food waste generation equated to $23 \pm 5 \mathrm{~kg} / \mathrm{employee} /$ year, of which $20 \pm 5$ $\mathrm{kg} / \mathrm{employee/year}$ was source-sorted, with a considerably high purity of $99 \%$. Residual waste amounted to $10 \pm 5 \mathrm{~kg} / \mathrm{employee} / \mathrm{year}$ and consisted mainly of paper $(29 \pm 13 \%)$,

36 plastic $(23 \pm 9 \%)$ and missorted food waste $(24 \pm 16 \%)$. The moisture content of source-

37 sorted food waste was significantly higher (8\%) than missorted food waste, and the methane potential of source-sorted food waste was $463 \pm 42 \mathrm{~mL} \mathrm{CH} 4 / \mathrm{g}$ VS. These results show that food waste in office areas offers promising potential for relatively

40 easily collectable and pure source-sorted food waste, suggesting that recycling targets

41 for food waste could be achieved with reasonable logistical ease in office areas.

\section{Keywords:}

44 Residual waste

45 Waste composition 
46 Biochemical methane potential

$47 \quad$ Sorting efficiency

48 Impurity

49 Waste sorting bins

50

51

Page 3 of 43 
531 Introduction

In the context of the circular economy and resource efficiency, the Danish

55 Government, in 2013, launched its Resource Strategy Plan, mandating that, by 2018, at

56 least $60 \%$ of food waste- that cannot be prevented or reduced - generated by the

57 service sector, including in office areas, should be source-sorted and collected separately (Danish Government, 2013). This source-sorted food waste should be treated

59 biologically to produce biogas and to recover nutrients (Danish Government, 2013).

60 Furthermore, numerous public and private companies and businesses as well as

61 institutions in the service sector are increasingly committed to sustainable development

62 through the prevention, reuse and recycling of their waste (European Commission,

63 2013; Lang et al., 2011; Phillips et al., 1999). In order to assess the current waste

64 situation, and to allow for any evaluation of performance against target indicators, data

65 on solid waste generation and composition are required. While recently many studies

66 have focused on source-sorted food waste at the household level (Bernstad, 2014;

67 Hansen et al., 2007b; Jansen et al., 2004; Vinnerås et al., 2006), waste data from the

68 service sector in general, and especially office areas, are limited (Christensen and

69 Fruergaard, 2010).

70 Waste from office areas typically consists of paper, packaging (e.g. board,

71 plastics, metals, etc.), waste from electrical and electronic equipment (WEEE),

72 hazardous waste and unsorted waste associated, for example, with food consumption

73 (Christensen and Fruergaard, 2010). The management of waste from office areas may

74 vary according to countries and office cultures; for instance, in Denmark paper,

75 packaging, WEEE and hazardous waste are source-sorted for either special treatment

76 (e.g. batteries, paint products, waste oil, etc.) or recycling (e.g. paper, board, plastic, 
WEEE, etc.), while unsorted waste currently is incinerated (Danish EPA, 2014a). This unsorted waste, in many cases, may represent a significant - or the most significant fraction of generated waste. As an example, the proportion of unsorted waste from the service sector that was incinerated in Denmark in 2012 accounted for up to $31 \%$ of the total waste (Danish EPA, 2014b).

Numerous studies have quantified and characterised unsorted waste generated in canteens, production kitchens and cafeteria in schools, at universities, hotels, restaurants and catering outlets (Armijo de Vega et al., 2008; Cordingley et al., 2011; Katajajuuri et al., 2014; Marthinsen et al., 2012, Mason et al., 2004; Mbuligwe, 2002; Smyth et al., 2010). Mason et al (2004) analysed source-sorted food waste from canteens, production kitchens and cafeteria at Massey University in New Zealand, but the study did not include office areas. Additionally, the waste generation data were presented as total waste for the university, thus limiting their applicability to other contexts. Composition data on unsorted waste from the service sector, and specifically

91 from office areas, is thus generally very limited, if at all available. In particular, data on 92 source sorting potential and efficiency, as well as the quality (e.g. content of impurities) of food waste generated from employees' lunches, coffee breaks, social events, etc., do not exist, as this waste is often collected and quantified as part of the mixed waste generated by institutions. However, the biologically degradable fraction of this otherwise unsorted waste may represent a valuable source of organic waste. In order to

97 assess whether the collection and specific management of food waste from office areas may contribute significantly to achieving food waste targets, concrete data for waste generation and the quality of the waste are needed. An additional shortfall in many of

100 the abovementioned studies is that the moisture content of waste is rarely measured, 101 even though it represents one of the key parameters affecting, for example, the 
102 biological treatment of waste, such as composting (Stentiford and de Bertoldi, 2010),

103 energy recovery (Hulgaard and Vehlow, 2010) and the environmental assessment of

104 waste treatment technology (Clavreul et al., 2012).

105 The overall aim of this case study was to quantify the potential for source-sorted

106 food waste in office areas, which was done by quantifying food waste generation rates,

107 source sorting efficiencies and the purity of sorted fractions for a selected office area

108 case study. Temporal variations (seasonal and daily) and the influences of a number of

109 employees were investigated. In addition, the moisture content and biochemical

110 methane potential of the collected source-sorted food waste were determined, and the

111 results were then evaluated with respect to how they may contribute to local and

112 national food waste management targets.

\section{Materials and methods}

$114 \quad 2.1$ Definitions

115 In this section, we describe the terminology used in this study. Food waste

116 refers to avoidable and unavoidable food waste, including drinks and beverage products

117 (WRAP, 2009), while residual waste refers to the remaining unsorted waste when food

118 waste has been taken out; this includes tissue paper, plastic film, food wrapping paper,

119 etc. (see Figure 1). A source-sorted waste fraction refers to a waste fraction that is

120 disposed of in the intended waste bin; for instance, source-sorted food waste is food

121 waste disposed of in a food waste bin. A missorted waste fraction refers to a waste

122 fraction disposed of in the wrong waste bin; for example, missorted residual waste is

123 residual waste disposed of in a food waste bin, and vice versa.

124 In the present study, the following waste fractions were not included: source-

125 sorted recyclable waste (see Section 1), WEEE and batteries, hazardous waste and

126 waste from canteens. The results of statistical analyses are given as probability values 
127 (p) and degrees of freedom (df), and the data are presented as mean and standard

128 deviations (Mean \pm SD) unless otherwise indicated. The waste generation rates are

129 expressed as mass wet waste per employee at work per working day, or mass wet waste

130 per employee at work per year, assuming 250 working days per year.

\section{$131 \quad 2.2$ Study area}

132 The study was carried out in the office area of the Department of Environmental

133 Engineering at Technical University of Denmark. The total number of employees was

134180 during the waste sampling campaign (DTU Environment, 2013). This office area

135 has four kitchens which are used by the employees for lunch, coffee breaks and social

136 events (e.g. birthdays, breakfast, etc.). The employees can also bring either their food

137 from home or buy from a canteen, supermarket, etc. In general, only hot drinks such as

138 coffee and tea are prepared in the kitchen. The mixed waste generated in this office area

139 is disposed of primarily in the waste bins placed in these kitchens. There are no bins in

140 the corridors for reasons of fire safety. Thus, in the course of this study, two plastic

141 waste bins of $60 \mathrm{~L}$ each were placed in each of the four kitchens: (1) food waste bins

142 were used for food leftovers, edible and inedible food, spent coffee grounds with paper

143 filters, tea bags, etc. (see Figure 1); (2) residual waste bins were used to dispose of all

144 other waste fractions (apart from food waste), including tissue papers, plastic film and

145 food packaging, beverage cartons, aluminium wrapping foil, etc. As a result, eight

146 waste bins were used for this sampling campaign, and they had stickers clearly stating

147 the name of the waste fractions (either source-sorted food waste or residual waste) that

148 should be disposed of in the bins. Sorting guidelines were also available on the

149 department website, while pamphlets explaining the waste sorting campaign were

150 delivered to individual offices (see Figure 1). 


\subsection{Waste sampling and analyses}

The study was conducted during 133 working days, corresponding to 29 weeks,

153 from $12^{\text {th }}$ February to $31^{\text {st }}$ August 2013. This period covered the winter, spring and

154 summer seasons. The waste was collected separately from each kitchen on a daily

155 basis; however, it was not collected during weekends and public holidays, when the

156 offices were officially closed.

157 We carried out four analyses. First, we collected and weighed separately the

158 waste from each bin in the four kitchens. This collected waste represented the total

159 mixed waste generated in this office area during the sampling period. However, the

160 food waste that is disposed of via other routes, such as sewer, etc., was not included in

161 this study. Furthermore, we used the existing employee online registration system to

162 obtain data on the number of employees who worked at the office during the study.

163 Second, once a week, we manually sorted the waste generated during a working day, to

164 determine the composition of source-sorted food waste and residual waste. The

165 working day was chosen successively every week to investigate possible daily

166 variations in waste composition. Source-sorted food waste and residual waste were

167 sorted into 30 waste fractions, as classified and described by Edjabou and co-authors

168 (2015). Third, we used the sorted waste samples to measure the moisture content of

169 source-sorted food waste and residual waste fractions throughout the sampling period

170 by drying the samples at $105^{\circ} \mathrm{C}$ until a constant weight (approximately 24 hours) was

171 attained. We then calculated moisture content according to equation (1) (CEN/TC 335,

172 2010):

173

$$
W C_{j}=\left(W_{j 1}-W_{j 2}\right) /\left(W_{j 1}-m_{j}\right) * 100
$$

where $W C_{j}$ is the moisture content of the material fraction $(j)$ as a percentage of wet waste, $W j_{1}$ is the mass of the waste fraction $(j)$ and the container before drying, $W j_{2}$ is 
176 the mass of the waste fraction $(j)$ and the container after drying, and $m_{j}$ is the mass of

177 the empty container. Fourth, we measured the biochemical methane potential of source-

178 sorted food waste. For this purpose, source-sorted food waste samples collected during

17929 days (total daily source-sorted food waste, about $8 \mathrm{~kg}$ ) and stored at $-20^{\circ} \mathrm{C}$ were

180 mixed mechanically by core-shredding (ARP SC 2000). To obtain representative

181 samples for the biochemical methane potential test, we reduced the mass of source-

182 sorted food waste (about $232 \mathrm{~kg}$ ) by laying samples in elongated 1-D multilayer piles

183 and subsequently removing cross-cut portions of the lot, leading to two separate

184 samples. This was repeated until we obtained the necessary sample size about $5 \mathrm{~kg}$.

185 Before the biochemical methane potential test, we determined the volatile solids (VS)

186 content of source-sorted food waste per wet mass in a muffle oven by measuring the

187 loss of volatile solids at $550^{\circ} \mathrm{C}$ (approximately 2 hours) (Lagerkvist et al., 2010). The

188 remaining fraction was defined as the ash content of the sample. We carried out

189 biochemical methane potential tests using triplicate reactors (total volume of a $1 \mathrm{~L}$ batch

190 reactor with a working volume of $400 \mathrm{~mL}$, of which $320 \mathrm{~mL}$ inoculum) with organic

191 loading rates of $3 \mathrm{~g} \mathrm{VS} / \mathrm{L}$ that were incubated at $55^{\circ} \mathrm{C}$ with $400 \mathrm{~mL}$ of inoculum from a

192 thermophilic biogas plant. We measured methane production during 28-day period on a

193 gas chromatograph (Hansen et al., 2004).

Figure 1 about here

\subsection{Food waste source sorting evaluation}

Based on Christensen and Matsufuji (2010), the following indicators were defined

197 to evaluate the source-sorted food waste campaign. Here SSFW is source-sorted food

198 waste, RW is residual waste and FW is food waste.

199 - The food waste potential $\left(P_{F W}\right)$ is the total amount of food waste generated,

200 consisting of correctly sorted source-sorted food waste $\left(M c_{S S F W}\right)$ and missorted 
food waste $\left(M m_{F W}\right)$ in the residual waste bins, as shown in Equation (2).

$$
P_{F W}=M c_{S S F}+M m_{F W}
$$

- The sorting efficiency $\left(E_{F W}\right)$ of food waste is the ratio of source-sorted food waste

$204\left(M_{S S F W}\right)$ and the potential of food waste $\left(P_{F W}\right)$, as shown in Equation (3):

$$
E_{F W}=M_{S S F W} / P_{F W}
$$

- Purity may determine the level of organic waste pre-treatment prior to treatment in

207 a biogas plant (Hansen et al., 2007a). The purity of source-sorted food waste

208 source-sorted food waste $\left(\mathrm{Pu}_{\mathrm{SSFW}}\right)$ is the ratio between the wet mass of "correctly"

209 sorted food waste, disposed of in the food waste bin ( $\left.\mathrm{Mc}_{\mathrm{SSFW}}\right)$, and the total waste

210 disposed of in the food waste bin ( $\left.\mathrm{M}_{\mathrm{SSFW}}\right)$, as shown in Equation (4). The "correct"

211 sorted food $\left(\mathrm{Mc}_{\mathrm{SSFW}}\right)$ is the difference between the wet mass of source-sorted food

212 waste $\left(\mathrm{M}_{\mathrm{SSFW}}\right)$ and the wet mass of missorted material fractions $\left(\mathrm{M} m_{R W}\right)$ found in

213 the food waste bin, as shown in Equation (5).

$$
P u_{S S F W}=M c_{S S F W} / M_{S S F W}
$$

$$
M c_{S S F W}=M_{S S F W}-M m_{R W}
$$

\subsection{Statistical analyses}

We applied statistical analyses, in order to assess (i) the quality of the waste

218 data obtained and (ii) the influence of weekday, month and season on solid waste

219 generation and its composition as well as moisture content. For this purpose, the

220 relationship between the amount of waste (source-sorted food waste and residual waste) and the number of employees registered during the sampling campaign was analysed by using a simple linear regression (Reimann et al., 2008). Furthermore, we applied

223 bootstrapping regression models (Fox and Weisberg, 2012) to investigate the influence

224 of weekdays and temporal variations (monthly and seasonal variations) on source- 
sorted food waste and residual waste generation and composition. Finally, we compared the moisture content of source-sorted food waste and missorted food waste (e.g. food waste disposed of in the residual waste bin), using two samples t-test (BEST) (Kruschke, 2012). We assessed the representativeness of the waste sample size (number of sampling days) by comparing three confidence intervals based on (1) bootstrap, (2) tdistribution and (3) normal distribution as a function of sample size, given a fixed standard deviation (Crawley, 2005; Sharma and McBean, 2007). The statistical analyses were modelled in the statistical and graphical programming language $\mathrm{R}$ (http://www.r-project.org).

\section{Results and discussion}

\subsection{Waste generation rates and assessment of the waste data and sample size}

Table 1 summarises the data on source-sorted food waste and residual waste.

238 The average amount of source-sorted food waste generated in the office area amounted to $8.07 \pm 2.34 \mathrm{~kg}$ per working day, whereas the residual waste was $4.08 \pm 1.69 \mathrm{~kg}$ per working day (see Table 1). The average number of employees at work was $99 \pm 20$, corresponding to $55 \pm 11 \%$ of the total employees (Table SM 1 and Figure SM 1). The

242 high variation in the number of employees at work during this study was due to the

243 official Danish summer holiday period (from $1^{\text {st }}$ May to $30^{\text {th }}$ September), where employees can take up to three weeks' vacation; for example, in July, up to $61 \%$ of the employees were away on holiday and did not therefore attend work. expressed as waste generated per employee, per pupil or per student (Christensen and

248 Fruergaard, 2010). The problem is that many studies use the total number of employees 
officially registered at the workplace to compute this unit generation rate (Cordingley et al., 2011; Mason et al., 2004; Mbuligwe, 2002). In practice, however, the number of employees who generate solid waste may vary substantially during the sampling period, because some employees may leave for holidays, external meetings, business travel, etc. Estimating unit generation rates based on the actual number of employees at work, rather than the total official number of employees, is crucial for the general planning of waste management (e.g. choice of the waste bin size, collection frequency, etc.) and for the assessment of temporal variations.

The assessment of the representativeness of the sample size (the number of working days covered by the sampling period) showed that confidence intervals declined considerably when the number of working days increased (Figure SM $2 \& 3$ ). For both source-sorted food waste and residual waste, confidence intervals narrowed rapidly after 20 working days but more slowly thereafter, and they became nearly constant after 60 working days. We could conclude that 133 working days is a markedly good sample range from which to obtain reliable estimates, whereas less than 20 working days is regarded as a small sample. Furthermore, given the standard deviation obtained in this case study, the results of the confidence interval analyses also indicated that 30 working days could be a sufficient sample size to provide reliable estimates.

Figure 2 shows the relationship between the wet mass of generated sourcesorted food waste and residual waste, and the number of employees registered at work 270 during the sampling campaign, which is illustrated by the linear lines of the best fit with 271 a 95\% confidence interval region (in grey) We observed some source-sorted food waste 272 and residual waste outliers that showed significant variations in waste generation in the 273 office area. These outliers could be due to the waste generated during celebrations, and 
274 so for this reason they were included in data processing. The number of employees at

275 work was highly correlated and statistically significant with discarded source-sorted

276 food waste mass $\left(\mathrm{R}^{2}=0.55\right.$, with a $95 \%$ confidence interval extending from 0.42 to

277 0.66); however, there was a small, but still statistically significant, correlation between

278 the number of employees at work and residual waste $\left(\mathrm{R}^{2}=0.30\right.$ with a $95 \%$ confidence

279 interval from 0.15 to 0.42 ). This difference in correlation coefficients could be

280 explained by the fact that residual waste consisted mainly of light material fractions,

281 and as a result we chose the unit generation rates as discarded mass per employee (at

282 work) per working day.

283 Source-sorted food waste amounted to $0.08 \pm 0.02 \mathrm{~kg}$ per employee at work per

284 working day, while it was $0.04 \pm 0.02 \mathrm{~kg}$ per employee at work per working day for

285 residual waste (Table 1). Assuming 250 working days per year, solid waste generation

286 was estimated at $20 \pm 5 \mathrm{~kg}$ of source-sorted food waste per employee per year and $10 \pm$

$2875 \mathrm{~kg}$ of residual waste per employee per year.

Table 1 about here

Figure 2 about here

\subsection{Waste composition of source-sorted food waste in office areas}

The amount of source-sorted food waste collected represented $67 \%$ of the total

292 waste generated in the office area and consisted primarily of spent coffee grounds (80 -

$29390 \%)$, edible food waste (1-2\%), leftovers and tea bags (8-9\%). This could explain the

294 strong correlation between food waste and the number of employees at work, since

295 coffee is made according to the number of employees in attendance. Material fractions

296 missorted into food waste were mainly light materials such as plastic film and

297 miscellaneous combustibles, and they amounted barely to $0.5 \%$ of the total. This 
relatively small proportion of missorted material fractions could also be explained by

299 the high moisture content of spent coffee grounds in comparison to the light mass of

300 residual waste such as plastics and foil.

\subsection{Waste composition of residual kitchen waste}

The amount of residual waste represented $33 \%$ of the total waste generated in

303 this office area and consisted predominantly of paper (e.g. $28 \pm 13 \%$ ), missorted food waste $(24 \pm 16 \%)$ and plastic waste $(23 \pm 9 \%)$ (Table 2$)$. Here, the paper waste fraction consisted mainly of tissue paper, which accounted for $23 \pm 13 \%$ of the total residual waste. The plastic waste fraction consisted primarily of plastic packaging ( $17 \pm 10 \%$ of the total residual waste), especially polyethylene terephthalate (PET/PETE, $7 \pm 7 \%$ of total residual waste) and polypropylene (PP, $4 \pm 4 \%$ of the residual waste) (Table 2).

\section{Table 2 about here}

\subsection{Evaluation of the source sorting campaign}

312 3. We calculated these data using source-sorted food waste and residual waste

313 composition (Table 2) and the equations presented in Section 2.4. The sorting

314 efficiency of food waste in the office area was calculated using Eq. (3) and amounted to

$31589 \%$ (wet mass) of the potential food waste. This result indicates that only $11 \%$ (wet mass) of the potential food waste was missorted in the residual waste bins, while

317 residual waste missorted in the food waste bins accounted only for $0.5 \%$ (wet mass) of

318 source-sorted food waste, indicating extremely high (>99\%) source-sorted food waste

319 's purity. Consequently, the potential unit generation rate of food waste was calculated

320 as $0.09 \pm 0.02 \mathrm{~kg}$ per employee per working day, corresponding to $23 \pm 5 \mathrm{~kg}$ per employee per year. 
323 higher than that reported for Scandinavian households, which is at the level of 25 to

$32450 \%$ (Table 4). Furthermore, the level of source-sorted food waste impurity from

325 households was higher in comparison to the office areas in this study, ranging typically

326 from 1 to 9\% mass (Bernstad et al., 2013a; Dahlén et al., 2007; Møller et al., 2013). For

327 example, Bernstad et al. (2013a) studied source-sorted food waste in a residential area

328 in Malmö in Sweden in 2009, and they found a sorting efficiency for food waste as low

329 as $25 \%$, with a level of incorrect sorting between 3 and $9 \%$. This sorting efficiency

330 barely increased to $35 \%$ after the installation of sorting equipment in households and

331 intensive awareness-raising campaigns (Bernstad, 2014). Consequently, these results

332 confirmed that source-sorted food waste in the office area represents a potential source

333 for the separate collection of high-quality food waste and suggest that a $60 \%$ recycling

334 target formulated by the Danish Government for food waste generated by the service 335 sector, including office areas, should be achievable.

Table 3 about here

337

338

\subsection{Moisture content}

The moisture content of source-sorted food waste and residual waste is presented in Table 5. Due to the extremely low content of missorted residual waste in the food waste bins, we only measured the moisture content of source-sorted food waste and 15 fractions from the residual waste.

Moisture content was $73 \pm 7 \%$ and $67 \pm 8 \%$ for source-sorted food waste and food waste missorted in the residual waste bins, respectively. The difference in moisture content between source-sorted food waste and missorted food waste was statistically evaluated, and the results indicate that the moisture content of source-sorted 
346 food waste was significantly higher than the missorted FW by about $9 \%$ (with a $95 \%$

347 confidence interval extending from 4 to 13). These significant differences between

348 missorted food waste and source-sorted food waste are explained by (i) the migration of

349 water content from food waste to light fractions such as paper and board in the residual

350 waste bin (Dahlén and Lagerkvist, 2008) and (ii) very low amounts of missorted

351 residual waste in the food waste bins (Figures SM 4 \& 5).

352 The moisture content of non-ferrous metal, consisting mostly of used aluminium

353 coffee capsules, was $36 \pm 10 \%$. This is high compared with the moisture content of

354 other metal fractions found in the residual waste (Table 5) as well as from household

355 waste typically at the level of 8-19\% (Riber et al., 2009). This high moisture content of

356 used aluminium coffee capsules is attributed to spent coffee grounds remaining in the

357 capsules. Except for used aluminium coffee capsules, the moisture content of residual

358 waste fractions in office areas was lower than that reported for residual household

359 waste (Riber et al., 2009), which suggests that the source sorting of food waste may

360 reduce the moisture content of residual waste fractions and could increase heating

361 value when residual waste is incinerated with energy recovery.

\section{$362 \quad 3.6$ Biogas potential}

The biochemical methane potential for source-sorted food waste measured in

364 the batch test amounted to $463 \pm 42 \mathrm{Nm}^{3} / \mathrm{t}$ VS (Table SM 2), which is similar to the

365 methane potential reported for household source-sorted food waste (Bernstad et al.,

366 2013b; Davidsson et al., 2007; Hansen et al., 2007a). The VS content in the source-

367 sorted food waste was $23 \%$, thereby suggesting a methane potential of $110 \mathrm{Nm}^{3} / \mathrm{t}$ wet

368 mass waste. 


\subsection{Factors influencing unit generation rates}

371

372

373

374

375

376

377

378

380

381

382

383

384

385

386

387

388

389

390

391

392

393

394

Variations in source-sorted food waste and residual waste unit generation rates as a function of weekdays are shown in Figure 3. The highest source-sorted food waste generation rate (23 $\pm 4 \mathrm{~kg} / \mathrm{employee} / \mathrm{year})$ was observed on Mondays, while the lowest (19 $\pm 5 \mathrm{~kg} / \mathrm{employee} /$ year) was recorded on Fridays. Similarly, the highest and lowest residual waste generation rates we observed were $12 \pm 3$ and $9 \pm 4 \mathrm{~kg} / \mathrm{employee} / \mathrm{year}$, recorded on Mondays and Tuesdays, respectively. The statistical analyses confirmed a significant difference in generation rates on weekdays for both source-sorted food waste $(p=0.02, d f=4)$ and residual waste $(p=0.03, d f=4)$. This significant difference was due to significantly higher amounts of waste collected on Mondays. The underlying explanation is that waste collected on Mondays included anything generated during the weekends and on the subsequent Monday, because although some employees may work during weekends and holidays, there is no waste collection during these periods. There were no significant differences between waste amounts generated Tuesday to Friday $(\mathrm{p}=0.10 ; \mathrm{df}=3$ for source-sorted food waste and $\mathrm{p}=0.48, \mathrm{df}=3$ for residual waste) (Table SM $3 \& 4)$.

Figure 4 shows variations in the source-sorted food waste and residual waste generation rates per working day and per month as a function of months. This graph shows that the highest daily source-sorted food waste generation rate was in June (21 \pm $3 \mathrm{~kg} / \mathrm{employee} / \mathrm{year})$ and the lowest in August (19 $\pm 4 \mathrm{~kg} / \mathrm{employee} / \mathrm{year})$. On the other hand, the highest daily residual waste generation rate was in June $(11 \pm 3$

$\mathrm{kg} / \mathrm{employee} / \mathrm{year})$ and the lowest in August $(9 \pm 3 \mathrm{~kg} / \mathrm{employee} / \mathrm{year})$. However, none of these differences was statistically significant $(\mathrm{p}=0.83, \mathrm{df}=6$ for SSWF and $\mathrm{p}=$ $0.25, \mathrm{df}=6$ for residual waste) (Table SM $5 \& 6$ ), which indicates that the sourcesorted food waste and residual waste unit generation rates were not significantly 
influenced by monthly variations.

396 Given that the office buildings in this case study are located at a university, we

397 also investigated the influence of students' activities on the waste generation rates of

398 the employees. For this reason, we assessed the effect of institutional activities

399 consisting of lecturing, exams and holidays on waste generation. The results suggest

400 that there was no significant effect of institutional activities on source-sorted food

401 waste $(\mathrm{p}=0.32, \mathrm{df}=2)$ and residual waste $(\mathrm{p}=0.43, \mathrm{df}=2)$ generation rates.

\section{Table 5 about here}

Figure 3 about here

\subsection{Factor influencing food waste sorting}

The composition of missorted residual waste fractions in the food waste bin was about $0.5 \%$ of the total source-sorted food waste (see Section 3.2.2). However, we

407 found that the percentage of food waste missorted in the residual waste bin varied 408 according to weekdays and months. We observed the highest percentage of missorted

409 food waste in February (33 $\pm 19 \%$ of the total residual waste), which could be

410 explained by the fact that the sorting campaign started in this month, and therefore it

411 took some time for the employees to get used to the system. Furthermore, the

412 percentage of missorted food waste decreased slightly in March (23 $\pm 9 \%)$, before it

413 increased progressively to reach $30 \pm 13 \%$ in May, and then dropped to its lowest level

414 in June $(18 \pm 17 \%)$. The low percentage of missorted food waste could be attributed to

415 an information campaign carried out at the beginning of the month, where the

416 preliminary results of the food waste sorting system were presented. However, none of

417 these differences in the percentage of missorted food waste was statistically significant,

418 thus suggesting that the incorrect sorting of food waste could be explained neither by 
the weekday and monthly variations nor by the awareness-raising campaign.

\subsection{Factors influencing moisture content}

In this study, we focused on the influence of monthly variations in source-sorted

423 food waste and missorted food waste moisture content. The moisture content of sourcesorted food waste varied between $73 \pm 5 \%$ in February and $62 \pm 18 \%$ in May, but this difference was not statistically significant $(\mathrm{p}>0.05$, $\mathrm{df}=5$ ). Similarly, we found no significant effect of monthly variations in missorted food waste moisture content, which could be explained by the fact that food waste was collected in office areas where the indoor temperature is nearly constant, and there was a great deal of spent coffee grounds, which was not significantly affected by seasonal variations.

\subsection{Implications and perspectives of the study}

In this study, source-sorted food waste accounted for $67 \pm 6 \%$ and residual waste $33 \pm 6 \%$ of the total waste in the office area. Missorted food waste amounted to $24 \pm 16 \%$ of residual waste. As a result, the potential food wastefood waste accounted for $75 \pm 16 \%$ of the total waste in the office area and corresponded to $23 \pm 5$ $\mathrm{kg} / \mathrm{employee} /$ year.

Both household food waste and methane potential were found in the literature and are presented in Table 4. Potential household food waste was estimated at $75 \mathrm{~kg}$ per person per year (Edjabou et al., 2013). Under the assumption that up to $35 \%$ of the potential food waste generated in households could be collected separately (Bernstad, 2014), expected household source-sorted food waste amounted to $26 \mathrm{~kg} /$ person/year. A comparison of food waste generation rates (both potential food waste and estimated source-sorted food waste ) between office areas and households (see Table 4) 
suggested that the unit generation rates of source-sorted food waste in office areas may

444 be comparable to households. However, the amount of food waste generated per office area could be considerably higher than for households, because office areas are usually used by more people (on average 73 employees per office area in Denmark (Statistics

447 Denmark, 2015)) than the average household size (2.2 person per household in

448 Denmark (Statistics Denmark, 2015)); for instance, $8.1 \pm 2.3 \mathrm{~kg}$ food waste was source-

449 sorted and collected per day from the current study area. Considering the Danish

450 conditions, this amount corresponds to potential food waste from about 11 Danish

451 households, meaning that 11 waste bins would be used to collect source-sorted food

452 waste from households. On the other hand, only four waste bins were used to collect

453 food waste in office areas in this case study. These results indicate that significant

454 amounts of food waste could be collected separately with reasonable logistical ease in 455 office areas.

The level of impurity in source-sorted food waste found in this case study was markedly lower than the values reported in the literature from Danish households. This suggests that good-quality source-sorted food waste could be collected in office areas.

Based on the literature review on the methane potential of household source-

460 sorted food waste (see Table 4), and the biochemical methane potential test results, we

461 calculated the total potential of biogas emanating from office areas and households.

462 Here, we used the estimated total number of employees in office areas instead of the

463 number of employees actually at work, because we were estimating the potential of

464 source-sorted food waste and methane that could be generated at the national level.

465 Assuming similar methane potential and unit generation rates for waste generated in

466 office areas across the country, and assuming that the total potential number of

467 employees working in office areas is 1.2 million in Denmark (Statistics Denmark, 
2015), we estimated that 2.5 million $\mathrm{m}^{3}$ methane could be generated per year in

469 Denmark from source-sorted food waste in office areas. Comparatively, 16 million $\mathrm{m}^{3}$

470 methane could be generated from source-sorted food waste in Danish households. countries, these data should be applied based on the definition of office area provided 473 in this study.

\section{Conclusions}

This study quantified the generation rates and composition of source-sorted food waste generated in office areas, and it investigated potential influential factors. We found that $0.08 \pm 0.018 \mathrm{~kg} / \mathrm{employee} /$ day of source-sorted food waste could be collected separately from office areas, with a very low level of impurity $(0.5 \%)$. Given the sorting efficiency $(89 \pm 28 \%$ of food waste potential) and the high purity of sourcesorted food waste, we can conclude that a $60 \%$ recycling target, formulated by the Danish Government for FW generated by the service sector, including office areas, should be achievable.

The amount of source-sorted food waste was not affected significantly by seasonal variations, but missorted food waste contributed considerably to the amount of residual waste, although it represented only $11 \pm 9 \%$ of the potential food waste.

487 Despite the fact that this study was conducted in office areas located at a university, the 488 amount of waste generated was not affected by the number of students. In the present study, the waste bins were placed in the employee kitchens; however, the implementation of food waste source sorting in office areas may vary considerably

491 according to the structure and office culture. Although the statistical significance of the 492 awareness-raising campaign on reducing the percentage of missorted food waste was 
493

494

496

497

498

499

500

501

502

503

504

505

506

507

508

509

510

511

\section{Supplementary materials}

513

514

515

516 food waste reported in the literature.

\section{Acknowledgments} this study.

not investigated, we found evidence that continuous information campaigns are necessary to maintain the participation of employees in these sorting activities.

The significant difference in moisture content between source-sorted food waste and missorted food waste suggested that the moisture content of food waste migrates to lighter residual waste materials such as paper, board and plastics. The methane potential obtained from biochemical methane potential tests for source-sorted food waste generated in office areas was comparable to the methane potential of household

The authors wish to acknowledge the Danish Strategic Research Council for financing this study via the IRMAR (Integrated Resource Management \& Recovery) project (nr. 11-116775). The Technical University of Denmark Environment's IT and

Graphic groups are also acknowledged for providing data on employees registered during the sampling campaign and helping with graphs. I also wish to express my gratitude to Camilla Thyregod and Henrik Spliid from the Technical University of Denmark Compute for their valuable contribution to the statistical analyses employed in

Supplementary materials contain detailed waste data used for calculations, boxplots that present the number of employees registered during the waste sampling campaign as a function of months and weekdays, curves that show the results of simulating sample size based on confidence intervals, histograms of the posterior 
517 distribution of the difference in mean and standard deviations of the moisture content,

518 detailed results of the biochemical methane potential test and bootstrapping regressions

519 and their confidence intervals. SMs are divided into tables (Table SM) and figures

520 (Figure SM).

521

Page 23 of 43 


\section{References}

524

525

526

527

528

529

530

531

532

533

534

535

536

537

538

539

540

541

542

543

544

545

546

547

548

549

550

551

552

553

554

555

Armijo de Vega, C., Ojeda Benítez, S., Ramírez Barreto, M.E., 2008. Solid waste characterization and recycling potential for a university campus. Waste Management 28 Supplement 1, S21-26.

Bernstad, A., 2014. Household food waste separation behavior and the importance of convenience. Waste Management 34, 1317-1323.

Bernstad, A., La Cour Jansen, J., Aspegren, A., 2013a. Door-stepping as a strategy for improved food waste recycling behaviour-Evaluation of a full-scale experiment. Resources, Conservation and Recycling 73, 94-103.

Bernstad, A., Malmquist, L., Truedsson, C., Jansen, la C.J., la Cour Jansen, J., 2013b. Need for improvements in physical pretreatment of source-separated household food waste. Waste Management 33, 746-54.

CEN/TC 335, 2010. Solid Biofuels - Methods for determination of moisture contentOven dry method- Part 3: Moisture in general analysis sample.

Christensen, T. H. and Fruergaard, T., 2010. Commercial and Institutional Waste, in: Christensen, T.H. (Ed.), Solid Waste Technology \& Management, Volume $1 \& 2$. John Wiley \& Sons, Ltd, Chichester, UK.

Christensen, T.H and Matsufuji, Y., 2010. Source Segregation and Collection of Source-Segregated Waste, in : Christensen, T.H. (Ed.), Solid Waste Technology \& Management, Volume 1 \& 2. John Wiley \& Sons, Ltd, Chichester, UK.

Clavreul, J., Guyonnet, D., Christensen, T.H., 2012. Quantifying uncertainty in LCAmodelling of waste management systems. Waste Management 32, 2482-2495.

Cordingley, F., Reeve, S., Stephenson, J., 2011. Food waste in schools. Banbury, UK.

Crawley, M.J., 2005. Statistics: An Introduction using R, American Statistician. John Wiley \& Sons Ltd., London, UK.

Dahlén, L., Lagerkvist, A., 2008. Methods for household waste composition studies. Waste Management 28, 1100-1112.

Dahlén, L., Vukicevic, S., Meijer, J.-E., Lagerkvist, A., 2007. Comparison of different collection systems for sorted household waste in Sweden. Waste Management 27, 1298-1305.

Danish EPA, 2014a. National Standard affaldsregulativer (National standard of waste regulation). URL https://www3.mst.dk/Nstar/Regulation/Search.aspx (accessed 9.10.14). 
Danish EPA, 2014b. ISAG. URL http://mst.dk/virksomhed-myndighed/affald/tal-foraffald/registrering-og-indberetning/isag/ (accessed 9.10.14).

Danish Government, 2013. Denmark without waste: recycle more -incinerate less. Danish Ministry of the Environment, Copenhagen, Denmark.

Davidsson, A., Gruvberger, C., Christensen, T.H., Hansen, T.L., Jansen, J. la C., 2007. Methane yield in source-sorted organic fraction of municipal solid waste. Waste Management 27, 406-414.

DTU Environment, 2013. Welcome to DTU Environment. URL http://www.env.dtu.dk/english/About (accessed 4.14.14).

Edjabou, M.E., Jensen, M.B., Götze, R., Pivnenko, K., Petersen, C., Scheutz, C., Astrup, T.F., 2015. Municipal solid waste composition: Sampling methodology, statistical analyses , and case study evaluation. Waste Management 36, 12-23.

Edjabou, V.M.E., Petersen, C., Scheutz, C., Astrup, T.F., 2013. Characterization of household food waste in Denmark. In: Cossu, R., He P., Kjeldsen P., Matsufuji Y., Reinhart D., Stegmann (Eds.), Sardinia 2013 Fourth International Waste Management and Landfill Symposium. Executive Summaries, pp. 60.

European Commission, 2013. SMES, Resource efficiency and green market, Brussels, Belgium.

Fox, J., Weisberg, S., 2012. Bootstrapping Regression Models in R, in: An R Companion to Applied Regression. SAGE, pp. 1-17.

Hansen, T.L., Jansen, J. 1 C., Davidsson, Å., Christensen, T.H., 2007a. Effects of pretreatment technologies on quantity and quality of source-sorted municipal organic waste for biogas recovery. Waste Managemt 27, 398-405.

Hansen, T.L., Jansen, J.L.C., Spliid, H., Davidsson, A., Christensen, T.H., $2007 \mathrm{~b}$. Composition of source-sorted municipal organic waste collected in Danish cities. Waste Managent 27, 510-518.

Hansen, T.L., Schmidt, J.E., Angelidaki, I., Marca, E., Jansen, J. la C., Mosbaek, H., Christensen, T.H., 2004. Method for determination of methane potentials of solid organic waste. Waste Management 24, 393-400.

Hulgaard, T., Vehlow, J., 2010. Incineration: Process and Technology, in: Christensen, T.H. (Ed.), Solid Waste Technology and Management. John Wiley \& Sons, Ltd, Chichester, UK, pp. $363-392$.

Jansen, J. la C., Spliid, H., Hansen, T.L., Svärd, A., Christensen, T.H., 2004. Assessment of sampling and chemical analysis of source-separated organic household waste. Waste Management 24, 541-549. 
Katajajuuri, J.-M., Silvennoinen, K., Hartikainen, H., Heikkilä, L., Reinikainen, A., 2014. Food waste in the Finnish food chain. Journal of Cleaner Production. 73, $322-329$

Kruschke, J.K., 2012. Bayesian Estimation Supersedes the t Test. Journal of Experimental Psychology: General. 142, 573-603.

Lagerkvist, A., Ecke, H., Christensen, T.H., 2010. Waste Characterization: Approaches and Methods, in: Solid Waste Technology \& Management. John Wiley \& Sons, Ltd, pp. 61-84.

Lang, P. P., Clugston, R. M., \& Calder, W., 2011. Critical Dimensions of Sustainability in Higher Education 1 Critical Dimensions of Sustainability in Higher Education 1 This chapter appeared originally in Sustainability and University Life, Walter Leal Filho ed..

Marthinsen, J., Sundt, P., Kaysen, O., Kirkevaag, K., 2012. Prevention of Food Waste in Restaurants, Hotels, Canteens and Catering. Nordic Council of Ministers, Copenhagen,Denmark.

Mason, I.., Oberender, A., Brooking, A.., 2004. Source separation and potential re-use of resource residuals at a university campus. Resources, Conservation and Recycling 40, 155-172.

Mbuligwe, S.E., 2002. Institutional solid waste management practices in developing countries: a case study of three academic institutions in Tanzania. Resources, Conservation and Recycling 35, 131-146.

Møller, J., Jensen, M., Kromann, M., Neidel, T., Jakobsen, J., 2013. Miljøogsamfunds $\varnothing$ konomisk vurdering af muligheder for $\emptyset$ get genanvendelse af papir, pap, plast, metal ogorganiskaffald fradagrenovation (Environmental and SocioEconomic Analysis of Possibilities for Increased Recycling of Paper, Cardboard, Metal and Organic Was. Copenhagen, Denmark.

Phillips, P.S., Read, A.D., Green, A.E., Bates, M.P., 1999. UK waste minimisation clubs: a contribution to sustainable waste management. Resources, Conservation and Recycling 27, 217-247.

Reimann, C., Filzmoser, P., Garrett, R., Dutter, R., 2008. Statistical Data Analysis Explained - Applied Environmental Statistics with R. John Wiley \& Sons, Chichester

Riber, C., Petersen, C., Christensen, T.H., 2009. Chemical composition of material fractions in Danish household waste. Waste Management 29, 1251-1257.

Sharma, M., McBean, E., 2007. A methodology for solid waste characterization based on diminishing marginal returns. Waste Management 27, 337-344. 
Smyth, D.P., Fredeen, A.L., Booth, A.L., 2010. Reducing solid waste in higher education: The first step towards "greening" a university campus. Resources,

Statistics Denmark, 2015. Housing. URL

631 http://www.dst.dk/en/Statistik/emner/boligforhold.aspx (accessed 12.21.13).

632

Stentiford, E., de Bertoldi, M., 2010. Composting: Process, in: Christensen, T.H. (Ed.), Solid Waste Technology \& Management. John Wiley \& Sons, Ltd, Chichester, $634 \quad$ UK, pp. 513-532.

635 Vinnerås, B., Palmquist, H., Balmér, P., Jönsson, H., 2006. The characteristics of 636 household wastewater and biodegradable solid waste-A proposal for new 637 Swedish design values. Urban Water Journal 3, 3-11.

638 WRAP, 2009. Household Food and Drink Waste in the UK, October. Banbury, UK. 


\section{$640 \quad$ List of Tables}

641

642

643

644 Table 1: Statistical description of solid waste generation from the office area and the

645 percentage of employees at work during the sampling campaign (number of working

646 days is 133$)$.

\begin{tabular}{|c|c|c|c|}
\hline Parameters & Median & Mean & Standard deviation \\
\hline \multicolumn{4}{|l|}{ Waste generation } \\
\hline Source-sorted food waste $\left(\mathrm{kg} \mathrm{ww}^{\mathrm{a}} / \text { working day }\right)^{\mathrm{b}}$ & 7.99 & 8.07 & 2.34 \\
\hline Source-sorted food waste ( $\mathrm{kg} \mathrm{ww}$ /employee ${ }^{\mathrm{d}} /$ working day) & 0.08 & 0.08 & 0.02 \\
\hline Residual waste $\left(\mathrm{kg} \mathrm{ww}^{\mathrm{a}}\right.$ /working day) ${ }^{\mathrm{b}}$ & 3.92 & 4.08 & 1.69 \\
\hline Residual waste (kg wwa/employee / /working day) & 0.04 & 0.04 & 0.02 \\
\hline \multicolumn{4}{|l|}{ Employees } \\
\hline Number of employees per working days & 105 & 99 & 20 \\
\hline Percentage of employees ${ }^{c}$ & 58 & 55 & 11 \\
\hline
\end{tabular}

647

Percentage of employees

$648{ }^{b}: k g$ wet mass waste per working day for the office area investigated.

$649{ }^{c}$ : Number employees per working days.

$650{ }^{d}$ :Employees at work.

651

652

653

654

655

656

657 
658 Table 2: Detailed composition of the waste generated in the office area in percentage of 659 wet mass.

\begin{tabular}{|c|c|c|c|c|c|c|}
\hline \multirow[t]{2}{*}{ Waste fraction } & \multicolumn{2}{|c|}{$\operatorname{SSFW}^{\mathrm{a}}\left(\% \mathrm{w} / \mathrm{w}^{\mathrm{c}}\right)$} & \multicolumn{2}{|c|}{$\mathrm{RW}^{\mathrm{b}}\left(\% \mathrm{w} / \mathrm{w}^{\mathrm{c}}\right)$} & \multicolumn{2}{|c|}{ Total $\left(\% \mathrm{w} / \mathrm{w}^{\mathrm{c}}\right)$} \\
\hline & Mean & $\mathrm{SD}$ & $\operatorname{Mean}\left(\% \mathrm{w} / \mathrm{w}^{\mathrm{c}}\right)$ & $\mathrm{SD}$ & Mean & SD \\
\hline Food waste & 99.6 & 0.01 & $24.0^{\mathrm{d}}$ & 15.9 & 74.5 & 16.1 \\
\hline Gardening waste & - & - & 0.0 & 0.0 & 0.0 & 0.0 \\
\hline Paper & - & - & 28.6 & 13.4 & 9.6 & 13.4 \\
\hline Tissue paper & - & - & 22.8 & 10.2 & 7.7 & 1.5 \\
\hline Other paper & - & - & 2.2 & 2.1 & 0.7 & $1.8^{\mathrm{f}}$ \\
\hline Paper (cleaned) ${ }^{\mathrm{e}}$ & - & - & $3.7^{4}$ & 7.4 & 1.2 & 2.5 \\
\hline Board & - & - & 16.1 & 7.5 & 5.4 & 7.5 \\
\hline Folding boxes & - & - & $1.9^{\mathrm{d}}$ & 2.6 & 0.6 & 2.0 \\
\hline Miscellaneous board & - & - & 14.6 & 7.4 & 4.9 & $1.5^{\mathrm{f}}$ \\
\hline Plastic & - & - & 22.9 & 9.4 & 7.7 & 9.4 \\
\hline Foam & - & - & 0.7 & 1.2 & 0.2 & 2.1 \\
\hline Composite plastic & - & - & 2.5 & 1.9 & 0.8 & 1.5 \\
\hline Pure plastic film & - & - & 2.6 & 2.2 & 0.9 & 1.5 \\
\hline Packaging plastic & - & - & 17.0 & 9.5 & 5.7 & $1.4^{\mathrm{f}}$ \\
\hline PET/PETE & - & - & 7.0 & 6.8 & 2.4 & 1.1 \\
\hline HDPE & - & - & 1.2 & 5.7 & 0.4 & 5.0 \\
\hline $\mathrm{PVC} / \mathrm{V}$ & - & - & 0.0 & 0.0 & 0.0 & 0.0 \\
\hline LDPE/LLDPE & - & - & 0.0 & 0.0 & 0.0 & 0.0 \\
\hline PP & - & - & 3.8 & 4.1 & 1.3 & 1.2 \\
\hline PS & - & - & 1.9 & 1.9 & 0.6 & 1.2 \\
\hline Other resins & - & - & 0.2 & 0.6 & 0.1 & 3.2 \\
\hline Unspecified & - & - & 2.9 & 2.2 & 1.0 & 1.0 \\
\hline Metal & - & - & 4.2 & 3.6 & 1.4 & 3.6 \\
\hline Aluminium wrapping foil & - & - & 1.3 & 1.0 & 0.4 & 2.8 \\
\hline Metal ferrous & - & - & 0.9 & 1.6 & 0.3 & 3.2 \\
\hline metal non ferrous & - & - & 1.3 & 1.3 & 0.4 & 2.9 \\
\hline Glass & - & - & $1.7^{4}$ & 4.7 & 0.6 & 4.7 \\
\hline Miscellaneous combustibles & $0.4^{\mathrm{d}}$ & 0.01 & 1.8 & 2.2 & 0.6 & 2.2 \\
\hline Inert & - & - & 0.3 & 1.2 & 0.1 & 1.2 \\
\hline Special waste & - & - & $0.5^{\mathrm{d}}$ & 3.1 & 0.2 & 3.1 \\
\hline Total & 100.0 & - & 100.0 & - & 100.0 & - \\
\hline
\end{tabular}

660

${ }^{a}$ : Source-sorted food waste.

$661{ }^{b}$ : Residual waste.

$662{ }^{c}$ : Wet mass.

$663{ }^{d}$ :Misplaced material fractions;

$66{ }^{e}$ : Paper (cleaned) consisted of offices papers, newspapers, magazines and advertisements.

665

Page 29 of 43 
666 Table 3: Overview of food waste generation rates, sorting efficiency and purity.

\begin{tabular}{lc}
\hline Parameters & Values \\
\hline Misplaced food waste in residual waste bins (\%) & $24 \pm 16$ \\
Purity of food waste (\%) & $99 \pm 0.01$ \\
Potential of food waste $\mathrm{ww}^{\mathrm{a}}$ (kg/employee/working day) & $0.091 \pm 0.02$ \\
Sorting efficiency of food waste (\%) & $89 \pm 28$ \\
Percentage of misplaced food waste as function of food waste potential (\%) & $11 \pm 9$ \\
\hline
\end{tabular}

667

${ }^{a}$ : wet mass

668 Table 4: Estimated potential of the amount of source-sorted food waste and biogas from

669 office area and households in Denmark.

\begin{tabular}{|c|c|c|c|c|}
\hline & \multicolumn{2}{|c|}{ Quantities } & \multicolumn{2}{|c|}{ Percentage $(\%)$} \\
\hline & Employee's kitchen & Household & Employee's kitchen & Household \\
\hline Potential food waste ( $\mathrm{kg}$ wet mass per year) & $23^{\mathrm{a}}$ & $75^{\mathrm{b}}$ & 23 & 77 \\
\hline Sorting efficiency (\%) & 89 & $35^{\mathrm{c}}$ & 35 & \\
\hline Expected SSFW (wet mass kg per year) & $20^{\mathrm{a}}$ & $26^{\mathrm{b}}$ & $43-26$ & $57-74$ \\
\hline Estimated total waste in Denmark ( ton wet mass) & $48,838^{\mathrm{d}}$ & $147,715^{\mathrm{e}}$ & - & - \\
\hline Methane potential $\left(\mathrm{Nm}^{3} /\right.$ ton wet waste $)$ & 110 & $109^{\mathrm{f}}$ & - & - \\
\hline Estimated total methane potential $\left(\mathrm{Nm}^{3}\right)$ & $4,542,391$ & $16,100,926$ & 14 & 86 \\
\hline
\end{tabular}

$670 \quad{ }^{a}:$ wet mass kg per employee per year.

$671{ }^{b}$ : wet mass kg per person per year (Edjabou et al., 2013).

$672 \quad{ }^{c}:($ Bernstad, 2014)

$673{ }^{d}$ : estimated total source sorted food waste based on 2 million employees working in office areas in 674 Denmark (see section 3.7) (Statistics Denmark, 2015).

$675{ }^{e}$ : estimated total source-sorted food waste based on 5.6 million inhabitants in Denmark (Statistics

676 Denmark, 2015).

$677{ }^{f}$ :(Hansen et al., 2007b)

678 
680 Table 5: Moisture contents of SSFW and RW fractions collected separately in the office 681 area.

\begin{tabular}{|c|c|c|c|c|}
\hline \multirow{2}{*}{ Waste fractions } & \multicolumn{2}{|c|}{$\operatorname{SSFW}(\%)^{\mathrm{a}}$} & \multicolumn{2}{|c|}{$\mathrm{RW}(\%)^{\mathrm{b}}$} \\
\hline & Mean & $S D^{f}$ & Mean & $\mathrm{SD}$ \\
\hline Food waste & 72.5 & 7.1 & $66.5^{\mathrm{c}}$ & $8.4^{\mathrm{c}}$ \\
\hline Paper & - & - & & \\
\hline Tissue paper & - & - & 35.8 & 9.7 \\
\hline Other paper & - & - & 14.6 & 6.6 \\
\hline Paper & - & - & 17.8 & 10.8 \\
\hline Board & - & - & & \\
\hline Folding boxes & - & - & 16.9 & 6.7 \\
\hline Miscellaneous board & - & - & 19.7 & 7.9 \\
\hline Beverage cartons & - & - & 24 & 1.4 \\
\hline Plastic & - & - & & \\
\hline Foam trays & - & - & 18.7 & 13.1 \\
\hline Composite plastic & - & - & 7.7 & 6.4 \\
\hline Pure plastic film & - & - & 8.5 & 7.3 \\
\hline Packaging plastic & - & - & 10.4 & 6.5 \\
\hline Metal & - & - & & \\
\hline Aluminium wrapping foil & - & - & 16.9 & 10.5 \\
\hline Metal ferrous & - & - & 4.8 & 0.8 \\
\hline Metal non-ferrous & - & - & 30.6 & 16.3 \\
\hline Miscellaneous combustible waste & - & - & 23.0 & 16.7 \\
\hline
\end{tabular}

$683{ }^{b}$ : Residual waste.

$684 \quad$ : Moisture content of misplaced food waste.

685 :Standard deviation

686

687

688 


\begin{tabular}{|l|l|}
\cline { 2 - 2 } \multicolumn{1}{c|}{ Food Waste (SSFW) } \\
\hline Avopted & Not accepted \\
\hline Unavoidable food waste & Tissue paper \\
Spent (used) coffee ground & Paper \\
Tea bags & Board \\
Flowers & Beverage carton \\
\hline
\end{tabular}

\begin{tabular}{|l|l|}
\cline { 2 - 2 } \multicolumn{2}{|c|}{ Residual Waste (RW) } \\
\hline \multicolumn{1}{|c|}{ Accepted } & \multicolumn{1}{|c|}{ Not accepted } \\
\hline Tissue paper & Paper \\
Plastic film & Corrugated boxes \\
Food wrapping paper & Glass \\
Aluminium wrapping foil & Metal packaging container \\
& Plastic packaging container \\
\hline
\end{tabular}

690 Figure 1: The waste sorting guide provided to employees

691

692

693
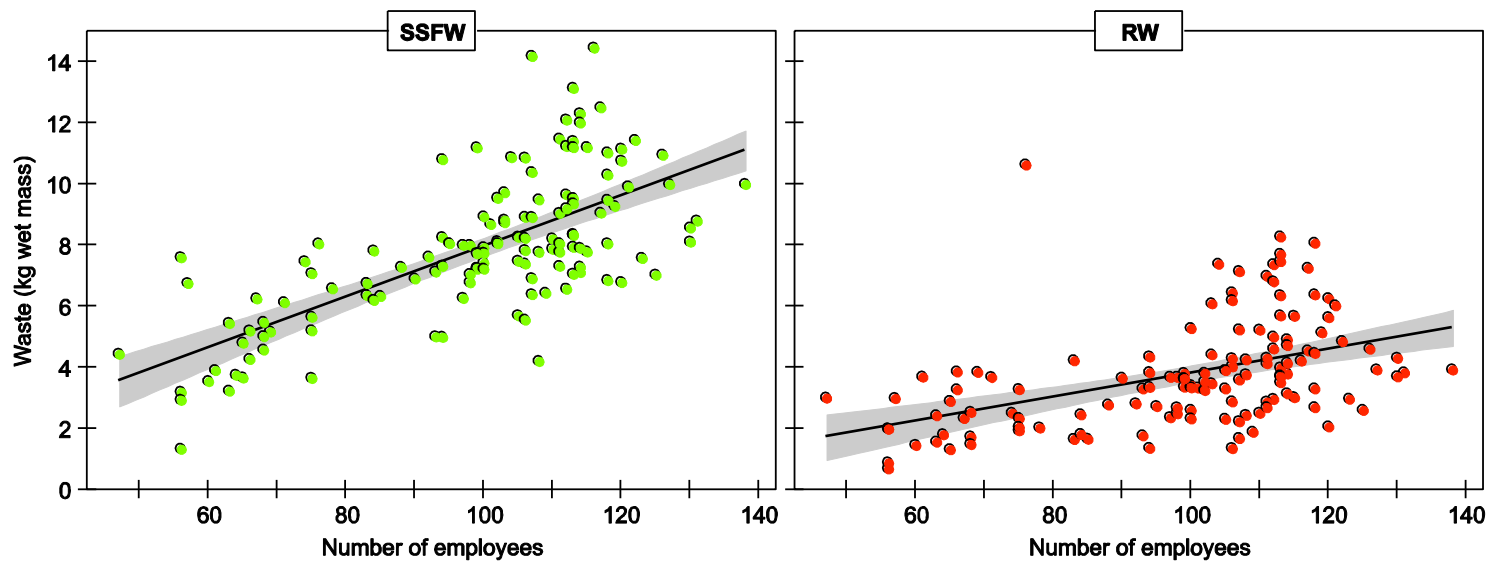

694 Figure 2: The relationship between the wet mass of waste generated and the number of

695 employees registered at work and the linear lines of best fit with $95 \%$ confidence

696 interval region (shown in grey).

697 


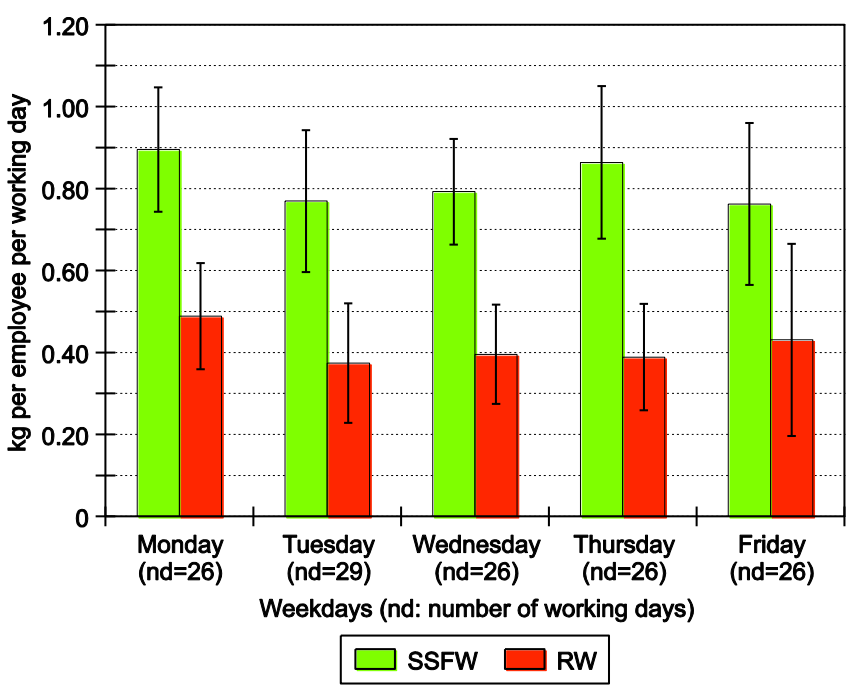

699 Figure 3: Average unit waste generation rates of source sorted food waste (SSFW) and 700 residual waste (RW) as a function of weekday.

701

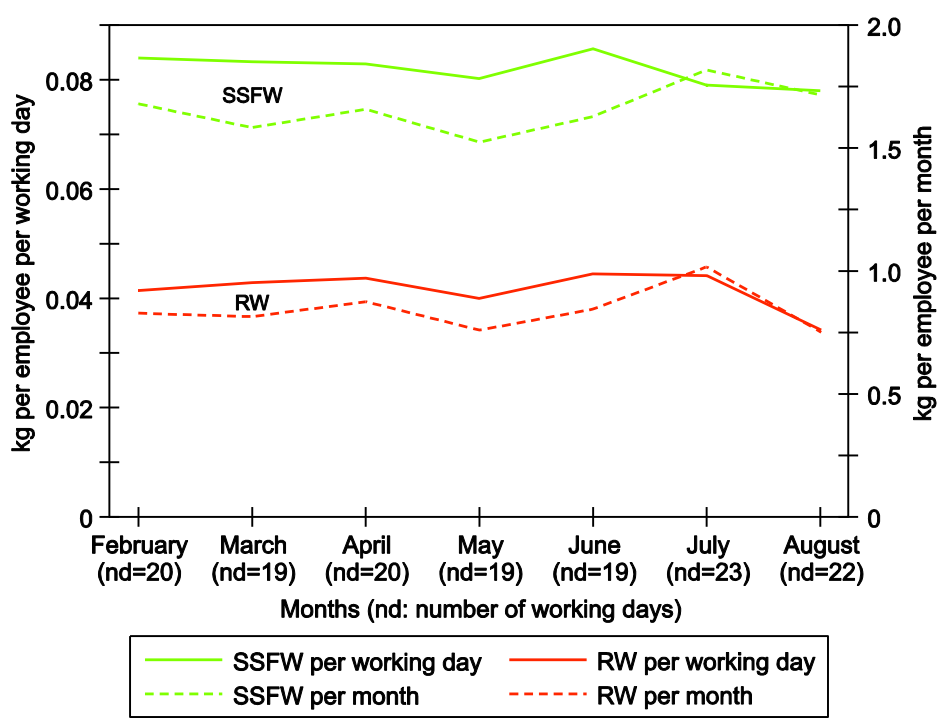

703 Figure 4: Unit generation rates of source-sorted food waste and residual waste during

704 the waste sampling campaign (kg per employee per working day and $\mathrm{kg}$ per employee 705 per month)

706 Supplementary materials for the paper: 


\section{quality}

711

712

713

Maklawe Essonanawe Edjabou*, Alessio Boldrin, Charlotte Scheutz, Thomas

714

Fruergaard Astrup

715

716

717 Department of Environmental Engineering, Technical University of Denmark, 2800

718

Kgs. Lyngby, Denmark

719

720

721

722

*) Corresponding author: vine@env.dtu.dk;

723

Phone numbers: +4545251498

724

725

Page 34 of 43 
727 Supplementary materials (SM)

728 Supplementary materials contain detailed waste data used for calculations, boxplots that

729 present the number of employees registered during the waste sampling campaign as a

730 function of months and weekdays, curves that show the results of simulating sample

731 size based on confidence intervals, histograms of the posterior distribution of the

732 difference in mean and standard deviations of the moisture content, detailed results of

733 the BMP test and bootstrapping regressions and their confidence intervals. SMs are

734 divided into tables (Table SM) and figures (Figure SM). 
Page 36 of 43 


\section{Supplementary materials-Tables}

738

739

740

741
742

743

744

745

746

747

748

749

750

751 752

Table SM 1: Overview of the waste sampling campaign showing the sampling period, the number of working days, the total number of employees at work, and amount of waste collected and analysed (wet mass).

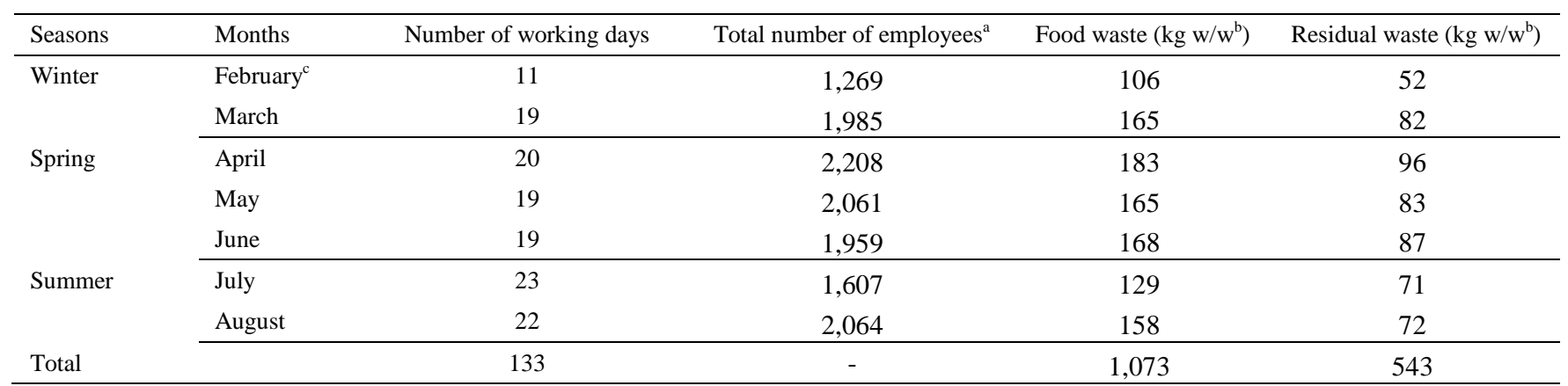

${ }^{a}:$ The total number of employees at office during the whole month.

${ }^{b}:$ Wet mass.

${ }^{c}$ : The waste sampling started on 12 February corresponding to 11working days.

Table SM 2: Statistical description of the results of the Biochemical Methane Potential (BMP) test

\begin{tabular}{lccc}
\hline Descriptive statistics & TS $(\% \text { w/w })^{\mathrm{a}}$ & VS $(\% \mathrm{w} / \mathrm{w})^{\mathrm{b}}$ & $\mathrm{BMP}_{\left(\left(\mathrm{CH}_{4} \mathrm{~mL} / \mathrm{g} \text { VS }\right)\right.}$ \\
\hline Number of samples & 12 & 12 & 8 \\
Median & 32 & 30 & 456 \\
Mean & 33 & 29 & 463 \\
Standard deviation (SD) & 6 & 4 & 42 \\
Standard error of the mean & 2 & 1 & 15 \\
Confidence interval of the mean $(0.95)$ & 4 & 3 & 35 \\
\hline
\end{tabular}

${ }^{a}$ Total solid in percentage of wet mass source-sorted food waste.

${ }^{b}$ Volatile Solid in percentage of wet mass source-sorted food waste.

Table SM 3: Summary of the bootstrapping of the relationship between the amount of residual waste and weekdays using 10,000 bootstrap samples

\begin{tabular}{lccccc}
\hline Variables (Days) & Original $^{\mathrm{a}}$ & \multirow{2}{*}{ BootBias $^{\mathrm{b}}$} & \multirow{2}{*}{ BootSE $^{\mathrm{c}}$} & \multicolumn{2}{c}{$95 \%$ Confidence intervals } \\
Lower & Upper \\
\hline Intercept (Monday) & 0.049 & 0.000 & 0.003 & 0.044 & 0.054 \\
Tuesday & -0.011 & 0.000 & 0.004 & -0.018 & -0.004 \\
Wednesday & -0.009 & 0.000 & 0.003 & -0.016 & -0.002 \\
Thursday & -0.010 & 0.000 & 0.004 & -0.017 & -0.003 \\
Friday & -0.006 & 0.000 & 0.005 & -0.014 & 0.009 \\
\hline
\end{tabular}

${ }^{a}$ Original residual waste sample means.

${ }^{b}$ The bootstrapped estimates of bias, which is the difference between the average bootstrapped value of the statistic(residual waste) and the original residual waste sample means .

${ }^{c}$ The bootstrapped estimates of standard error. 
Table SM 4: Summary of the bootstrapping of the relationship between the amount of source-sorted food waste and weekdays using 10,000 bootstrap samples

\begin{tabular}{|c|c|c|c|c|c|}
\hline \multirow{2}{*}{ Variables (Days) } & \multirow{2}{*}{ Original $^{\mathrm{a}}$} & \multirow{2}{*}{ BootBias $^{b}$} & \multirow{2}{*}{ BootSE $^{c}$} & \multicolumn{2}{|c|}{$95 \%$ Confidence intervals } \\
\hline & & & & Lower & Upper \\
\hline Intercept (Monday) & 0.090 & 0.000 & 0.003 & 0.084 & 0.096 \\
\hline Tuesday & -0.013 & 0.000 & 0.004 & -0.021 & -0.004 \\
\hline Wednesday & -0.010 & 0.000 & 0.004 & -0.018 & -0.003 \\
\hline Thursday & -0.003 & 0.000 & 0.005 & -0.012 & 0.007 \\
\hline Friday & -0.013 & 0.000 & 0.005 & -0.023 & -0.004 \\
\hline
\end{tabular}

${ }^{a}$ Original source-sorted food waste sample means.

$769{ }^{b}$ The bootstrapped estimates of bias, which is the difference between the average bootstrapped value of

770 the statistic(source-sorted food waste) and the original source-sorted food waste sample means .

$771{ }^{c}$ The bootstrapped estimates of standard error.

Table SM 5: Summary of the bootstrapping of the relationship between the amount of residual waste and months using 10,000 bootstrap samples

\begin{tabular}{|c|c|c|c|c|c|}
\hline \multirow{2}{*}{ Variables (Months) } & \multirow{2}{*}{ Original $^{\mathrm{a}}$} & \multirow{2}{*}{ BootBias $^{b}$} & \multirow{2}{*}{ BootSE $^{\mathrm{c}}$} & \multicolumn{2}{|c|}{$95 \%$ Confidence intervals } \\
\hline & & & & Lower & Upper \\
\hline Intercept (February) & 0.041 & 0.000 & 0.005 & 0.033 & 0.051 \\
\hline March & 0.001 & 0.000 & 0.005 & -0.009 & 0.012 \\
\hline April & 0.002 & 0.000 & 0.006 & -0.009 & 0.013 \\
\hline May & -0.001 & 0.000 & 0.006 & -0.013 & 0.011 \\
\hline June & 0.003 & 0.000 & 0.005 & -0.007 & 0.013 \\
\hline July & 0.003 & 0.000 & 0.007 & -0.009 & 0.019 \\
\hline August & -0.007 & 0.000 & 0.005 & -0.018 & 0.003 \\
\hline
\end{tabular}

${ }^{a}$ Original residual waste sample means.

$777{ }^{b}$ The bootstrapped estimates of bias, which is the difference between the average bootstrapped value of

778 the statistic(residual waste) and the original residual waste sample means.

$779{ }^{c}$ The bootstrapped estimates of standard error.

783 Table SM 6: Summary of the bootstrapping of the relationship between the amount of source-sorted food waste and months using 10,000 bootstrap samples

\begin{tabular}{|c|c|c|c|c|c|}
\hline \multirow{2}{*}{ Variables (Months) } & \multirow{2}{*}{ Original $^{\mathrm{a}}$} & \multirow{2}{*}{ BootBias $^{b}$} & \multirow{2}{*}{ BootSE $^{c}$} & \multicolumn{2}{|c|}{$95 \%$ Confidence intervals } \\
\hline & & & & Lower & Upper \\
\hline Intercept (February) & 0.084 & 0.000 & 0.005 & 0.074 & 0.093 \\
\hline March & -0.001 & 0.000 & 0.007 & -0.013 & 0.013 \\
\hline April & -0.001 & 0.000 & 0.006 & -0.012 & 0.011 \\
\hline May & -0.004 & 0.000 & 0.007 & -0.016 & 0.010 \\
\hline June & 0.002 & 0.000 & 0.006 & -0.009 & 0.013 \\
\hline July & -0.005 & 0.000 & 0.007 & -0.017 & 0.009 \\
\hline August & -0.006 & 0.000 & 0.006 & -0.016 & 0.007 \\
\hline
\end{tabular}

${ }^{a}$ Original source-sorted food waste sample means.

$786{ }^{b}$ The bootstrapped estimates of bias, which is the difference between the average bootstrapped value of

787 the statistic(source-sorted food waste) and the original source-sorted food waste sample means .

$788{ }^{c}$ The bootstrapped estimates of standard error. 
789

790

Page 39 of 43 


\section{Supplementary materials- Figures}

793 Figure SM 1: Summary of employees registered during the waste sampling campaign

794 (officially 180 employees were employed at the department during in 2013)
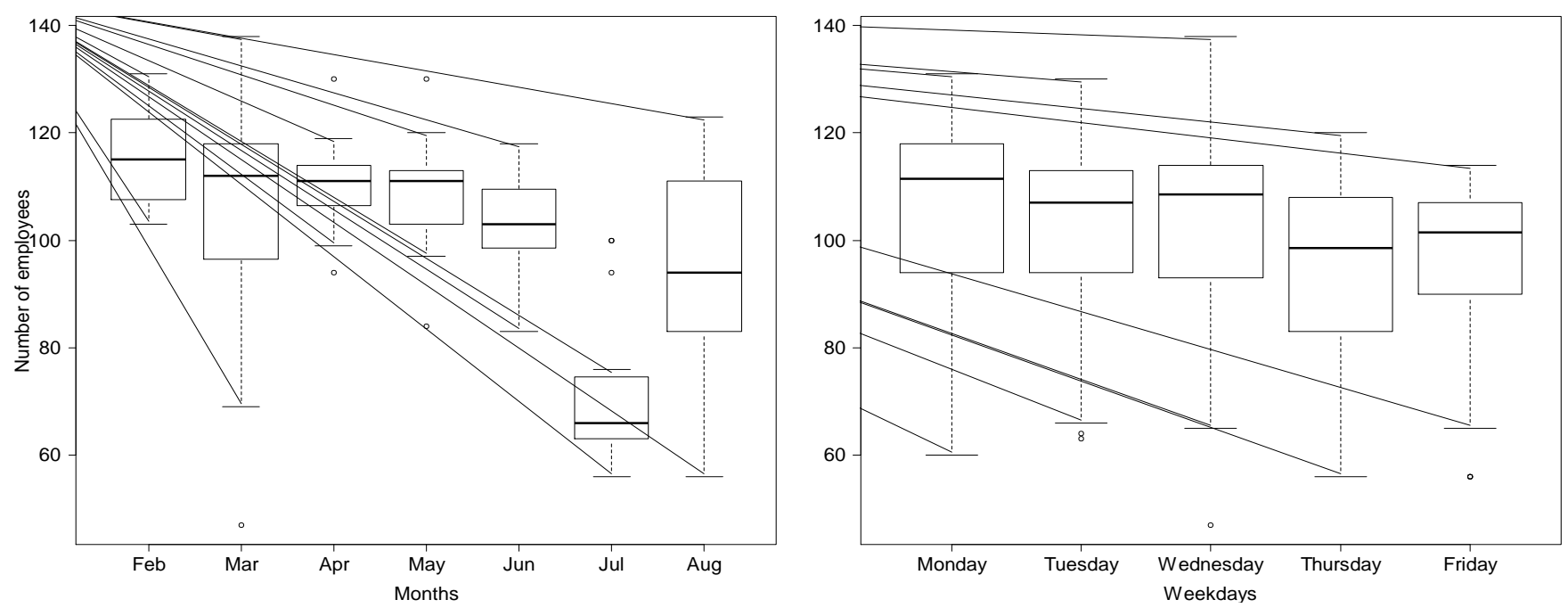

Figure SM 2: Simulation of confidence intervals (CI) of source-sorted food waste (SSFW) as function of sample size (number of working days)

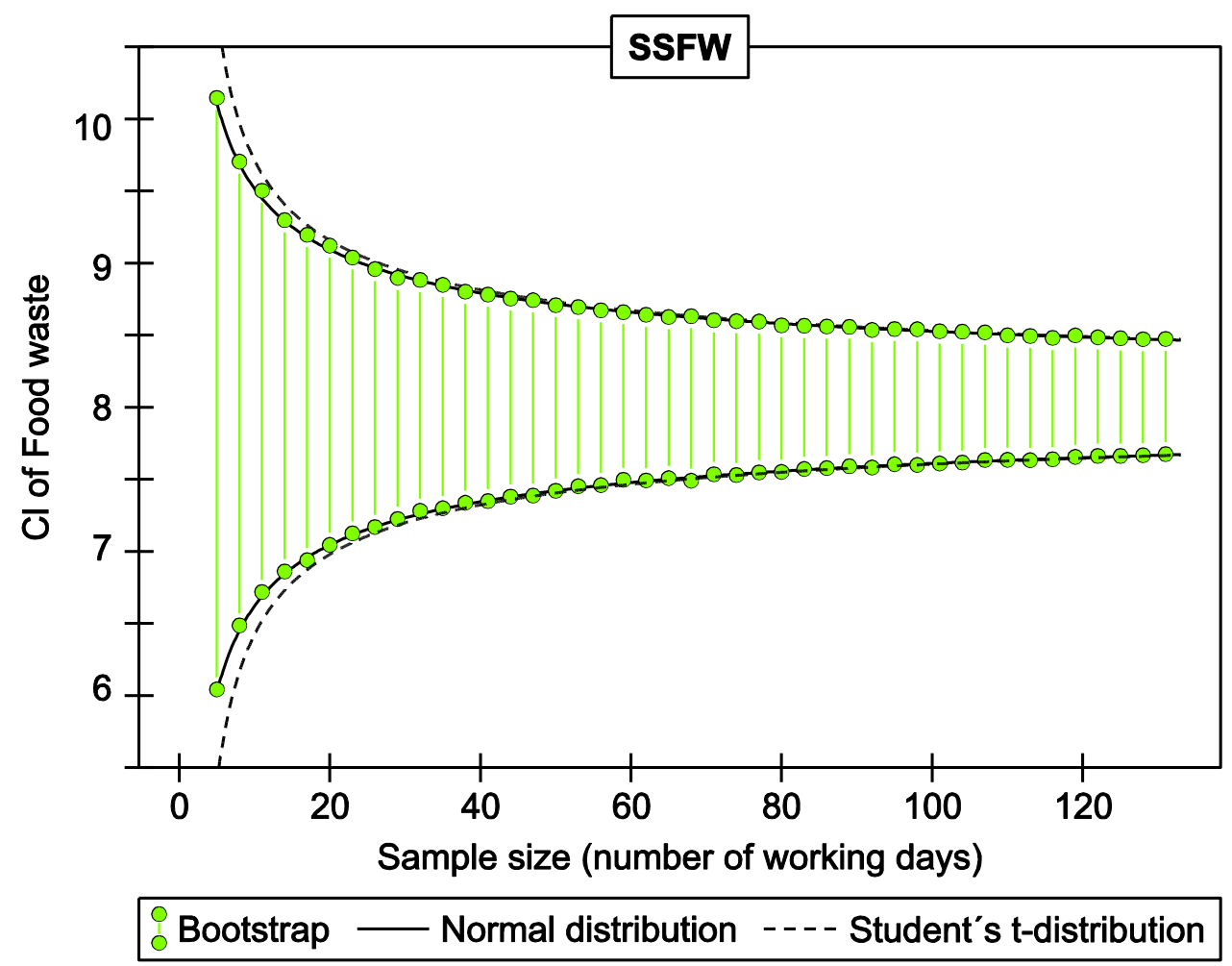


801

802

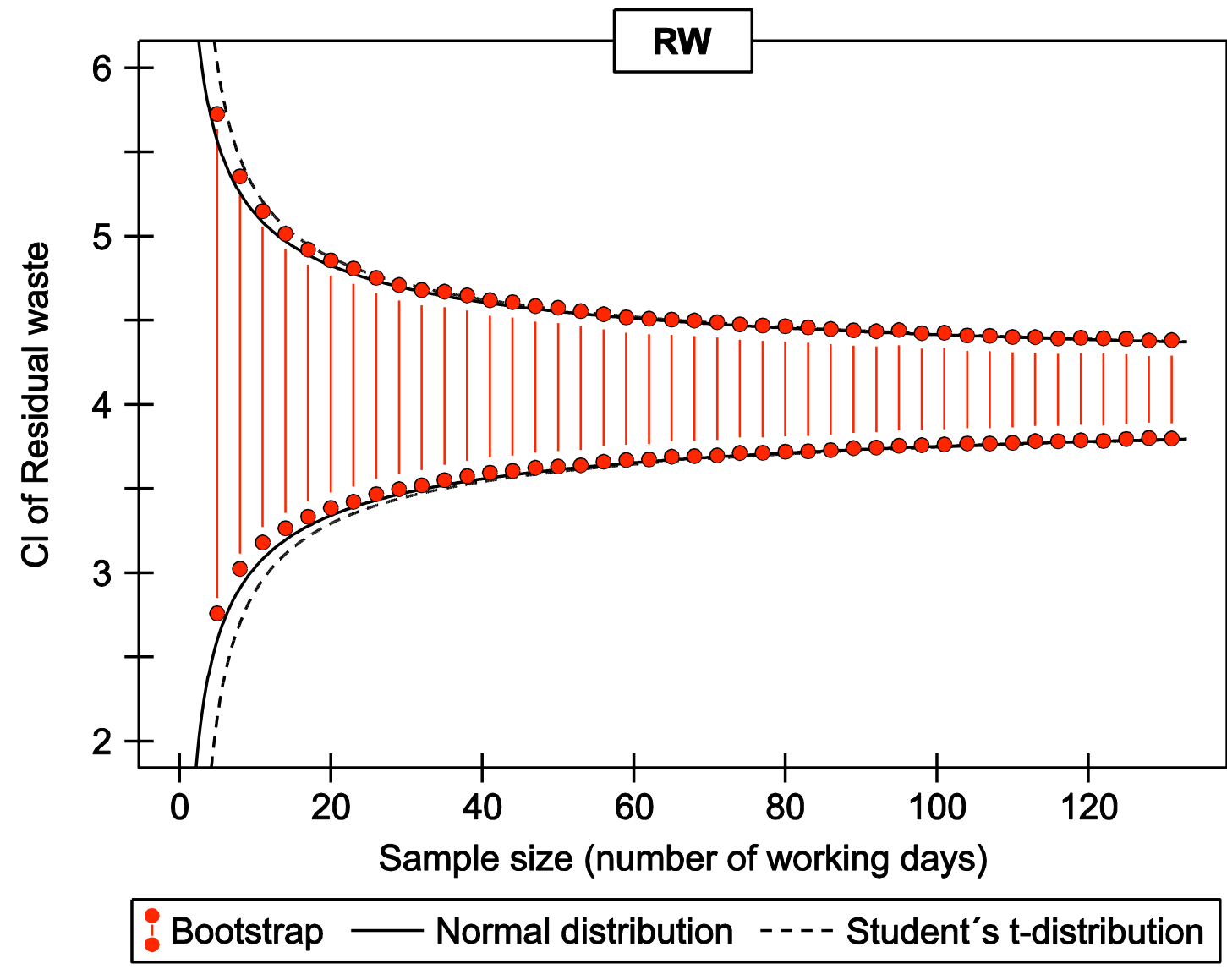

803

Figure SM 3: Simulation of confidence intervals (CI) of residual waste (RW) as function of sample size (number of working days)

804 
Figure SM 4: Histogram descripting the distribution of the difference in means values between source sorted food waste (SSFW) and misplaced food waste in residual waste bins

808

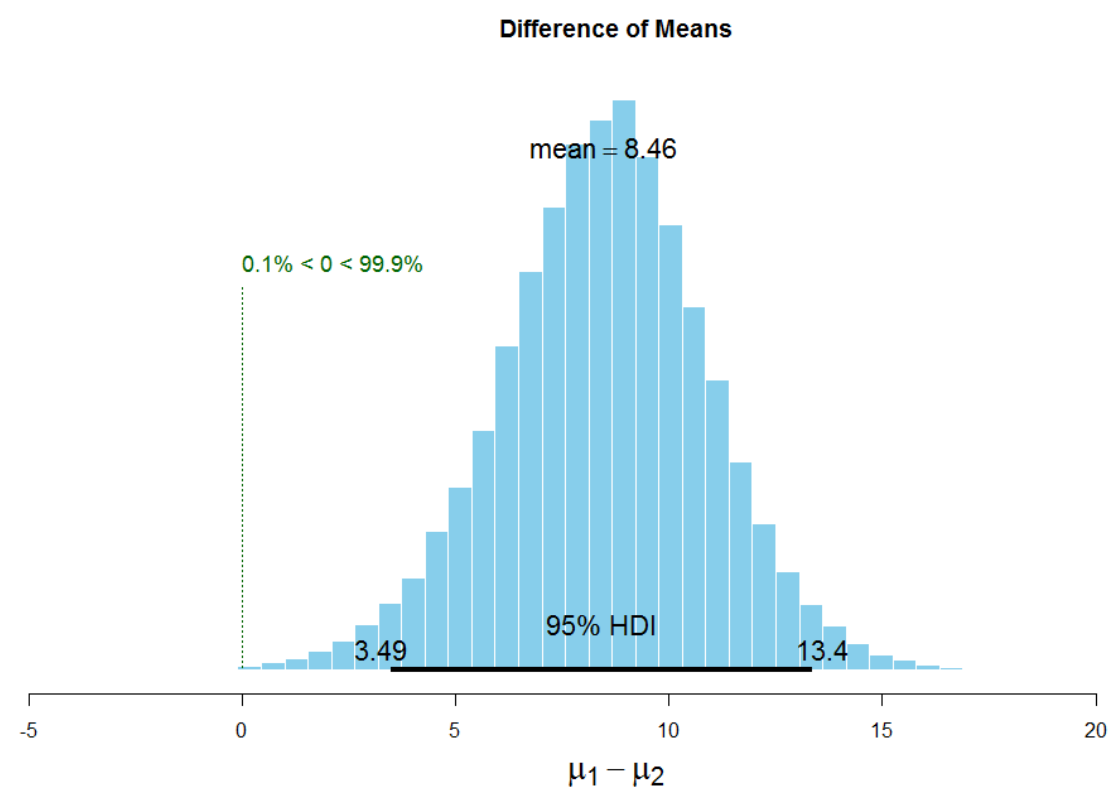

809

Figure SM 5: Histogram descripting the distribution of the difference in standard deviations between source sorted food waste (SSFW) and misplaced food waste in residual waste bins

Difference of Std. Dev.s

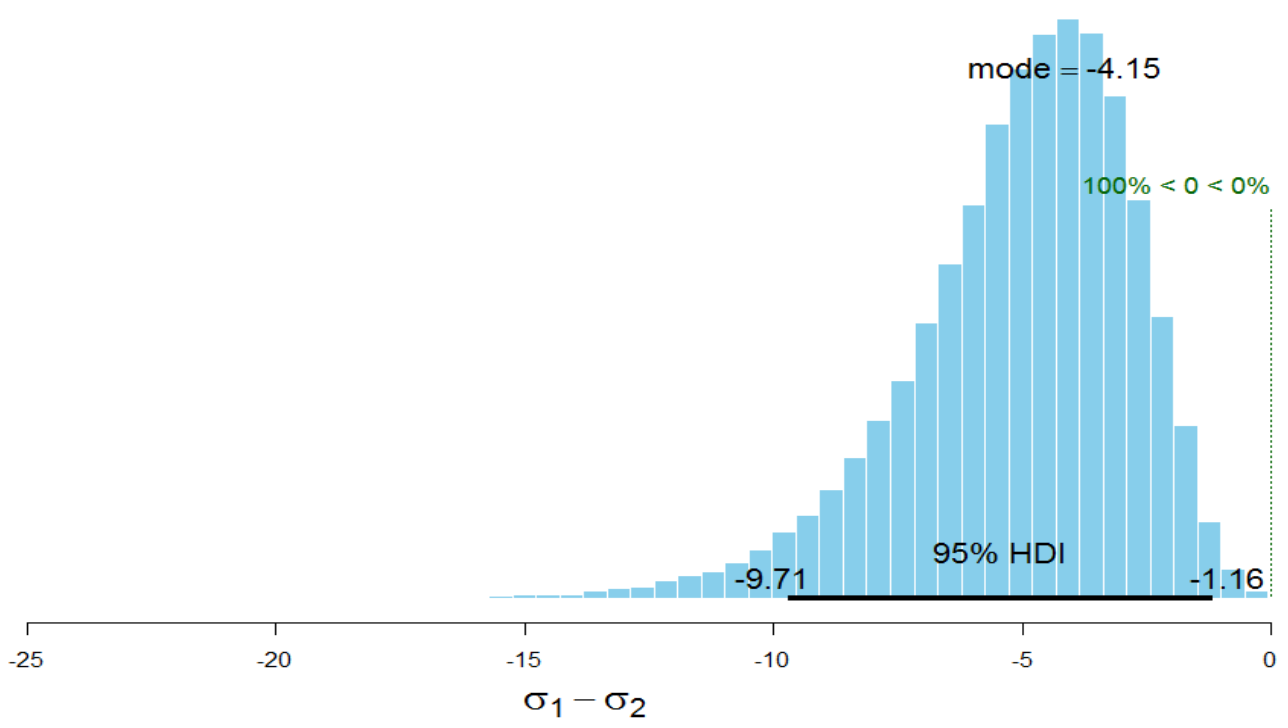

(1) $\sigma_{1}-\sigma_{2}$

814 (2) HDI: Highest density interval.

$815 \quad$ (3) $\mu_{1}$ : means of moisture content of source-sorted food waste.

$816 \quad$ (4) $\mu_{2}:$ means of moisture content of misplaced food waste.

817 (5) Std. Dev.s: standard deviation.

818 (6) $\sigma_{1}$ : standard deviation of moisture content of source-sorted food waste. 
821

822

823

Page 43 of 43 